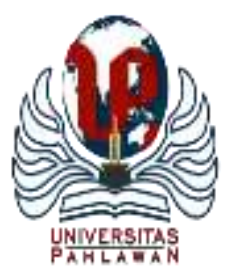

Edukatif : Jurnal Ilmu Pendidikan Volume 4 Nomor 1 Tahun 2022 Halm 133 - 140

EDUKATIF: JURNAL ILMU PENDIDIKAN

Research \& Learning in Education

https:/ledukatif.org/index.php/edukatif/index

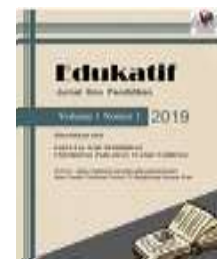

\title{
Profil Minat dan Hasil Belajar IPA Siswa Melalui Belajar dari Rumah pada Masa Pandemi Covid-19 di Sekolah Menengah Pertama
}

\author{
Andrianus Nggong ${ }^{1}$, Adrianus Nasar ${ }^{2 凶}$, Hamsa $^{\circledR 0 a}{ }^{3}$ \\ Program Studi Pendidikan Fisika FKIP Universitas Flores, Indonesia ${ }^{1,2,3}$ \\ E-mail : Andianusngong@gmail.com ${ }^{1}, \underline{\text { adrianus710@ gmail.com }}^{2}, \underline{\text { hamsadoa29@gmail.com }}^{3}$
}

\begin{abstract}
Abstrak
Penelitian ini bertujuan untuk mengetahui profil minat belajar IPA dan hasil belajar IPA melalui belajar dari rumah pada siswa kelas VIII SMPN 1 Nangapanda pada masa pandemi Covid-19. Jenis penelitian ini adalah ex post facto dengan pendekatannya deskriptif kuantitatif. Subjek penelitian berjumlah 55 siswa yang diperoleh melalui sampling jenuh. Pengumpulan data dilakukan dengan teknik angket untuk minat belajar dan teknik dokumentasi untuk hasil belajar. Analisis data pada penelitian ini menggunakan teknik analisis statistik deskriptif. Hasil penelitian menunjukkan: 1) Profil minat belajar IPA melalui belajar dari rumah pada masa pandemi covid-19 tahun pelajaran 2020/2021 adalah 69,1\% pada kualifikasi cukup baik dan 30,1\% pada kualifikasi kurang baik; 2) Profil hasil belajar IPA melalui belajar dari rumah pada masa pandemi covid-19 tahun pelajaran 2020/2021 adalah siswa yang berpersentase 47,27 \% dengan kualifikasi hasil belajar baik, siswa berpersentase $41,82 \%$ dengan kualifikasi hasil belajar cukup baik dan siswa berpersentase $10,91 \%$ dengan kualifikasi kurang baik.
\end{abstract}

Kata kunci: minat belajar, hasil belajar, pandemik Covid-19

\begin{abstract}
This study aims to determine the profile of interest in science learning and science learning outcomes through learning from home in class VIII SMPN 1 Nangapanda during the covid-19 pandemic. This type of research is ex post facto with a quantitative descriptive approach. The research subjects were 55 students who were obtained through saturated sampling. Data was collected using a questionnaire technique for learning interest and documentation techniques for learning outcomes. Data analysis in this study used descriptive statistical analysis techniques. The results showed: 1) The profile of interest in learning science through learning from home during the COVID-19 pandemic for the 2020/2021 school year was $69.1 \%$ in good enough qualifications and $30.1 \%$ in poor qualifications; 2) The profile of science learning outcomes through studying from home during the COVID-19 pandemic for the 2020/2021 academic year are students with a percentage of $47.27 \%$ with good learning outcomes qualifications, students with a percentage of $41.82 \%$ with quite good learning outcomes qualifications and students with a high percentage of $10.91 \%$ with poor qualifications.
\end{abstract}

Keywords: interest in learning, learning outcomes, the Covid-19 pandemic

Copyright (c) 2022 Andrianus Nggong, Adrianus Nasar, Hamsa Doa

$\triangle$ Corresponding author

Email : adrianus710@gmail.com

DOI : https://doi.org/10.31004/edukatif.v4i1.1723

ISSN 2656-8063 (Media Cetak)

ISSN 2656-8071 (Media Online)

Edukatif : Jurnal Ilmu Pendidikan Vol 4 No 1 Tahun 2022 p-ISSN 2656-8063 e-ISSN 2656-8071 
134 Profil Minat dan Hasil Belajar IPA Siswa Melalui Belajar dari Rumah pada Masa Pandemi Covid-19 di Sekolah Menengah Pertama - Andrianus Nggong, Adrianus Nasar, Hamsa Doa

DOI: https://doi.org/10.31004/edukatif.v4i1.1723

\section{PENDAHULUAN}

Pandemi Covid 19 berdampak pada seluruh aspek kehidupan manusia salah satunya adalah aspek pendidikan. Kebijakan yang diambil oleh negara yang terdampak virus corona termasuk Indonesia harus meliburkan sekolah untuk sementara. Agar pendidikan tetap terlaksana meskipun sekolah diliburkan sementara maka, pemerintah mencari solusi supaya proses pembelajaran selama pandemi Covid 19 tetap berjalan. Salah satu alternatif yang di ambil pemerintah adalah pembelajaran jarak jauh secara online. Upaya ini dilakukan supaya menjaga jarak diantara pendidik dan peserta didik, menjauhi aktivitas dalam segala bentuk kerumunan, perkumpulan, dan menghindari adanya pertemuan yang melibatkan banyak orang. Upaya tersebut juga dilakukan untuk memutus rantai penyebaran pandemi Covid-19.

Peraturan tersebut tentulah mengubah paradigma proses pendidikan yang sebelumnya pembelajaran dijalankan secara langsung atau tata muka sekarang dijalankan secara daring dengan memanfaatkan berbagai platform sebagai sarana pembelajaran (Godber \& Atkins, 2021). Pembelajaran online atau daring merupakan salah satu solusi yang efektif dalam situasi pandemi Covid 19. Pembelajaran online yaitu suatu kegiatan belajar yang membutuhkan jaringan internet dengan konektivitas, aksesibilitas, fleksibilitas, serta kemampuan untuk memunculkan berbagai jenis interaksi pembelajaran. Proses belajar dari rumah atau secara daring dilaksanakan dengan ketentuan yaitu aktivitas dan tugas pembelajaran belajar dari rumah dapat bervariasi antarsiswa, sesuai minat dan kondisi masing-masing, termasuk mempertimbangkan kesenjangan akses/fasilitas belajar di rumah (Kemendikbud 1, 2020).

Kemampuan dalam pembelajaran secara online masih banyak siswa, guru belum mahir terutama bagi siswa ataupun guru yang berada di daerah daerah pedalam. Pembelajaran daring merupakan pemanfaatan jaringan internet dalam proses pembelajaran. Dengan pembelajaran jarak jauh/ daring baik siswa maupun guru memiliki keleluasaan waktu dalam pelaksanaannya. Adapun platform yang dapat digunakan dalam pembelajaran jarak jauh ini antara lain: google classroom, goggle meet, zoom, Wa grup dan lain-lain.

Pembelajaran jarak jauh yaitu belajar dari rumah (BDR). Prinsip dari Kegiatan Belajar dari Rumah (BDR) ini adalah kegiatan BDR dilaksanakan untuk memberikan pengalaman belajar yang bermakna bagi peserta didik, tanpa terbebani tuntutan menuntaskan seluruh capaian kurikulum, aktivitas dan penugasan selama BDR dapat bervariasi antar daerah, satuan pendidikan dan peserta didik sesuai minat dan kondisi masing-masing, termasuk mempertimbangkan kesenjangan akses terhadap fasilitas BDR, hasil belajar peserta didik selama BDR diberi umpan balik yang bersifat kualitatif dan berguna dari guru tanpa diharuskan memberi skor/nilai kuantitatif dan mengedepankan pola interaksi dan komunikasi yang positif antara guru dengan orang tua/wali (Kemendikbud 2, 2020). Hal ini sejalan dengan penelitian yang dilakukan oleh (Zainal Abidin, Adeng Hudaya \& Dinda Anjani, 2020) mengatakan bahwa proses pembelajaran daring yang dilakukan saat ini cukup efektif meskipun disana-sini masih ada beberapa hambatan yang mengganggu pembelajaran jarak jauh seperti masalah interaksi sosial guru dengan siswa dan ekonomi peserta didik yang nyaris belum siap.

Pembelajaran jarak jauh (PJJ) yang dilakukan di SMPN 1 Nangapanda selama masa pandemi Covid 19 yaitu belajar dari rumah (BDR) dengan menggunakan pendekatan 1) Pembelajaran jarak jauh Dalam Jaringan/online (Daring), menggunakan gawai (gadget) maupun laptop melalui beberapa platform seperti google classroom, goggle meet, zoom, Wa grup dan lain-lain; 2) Pembelajaran jarak jauh Luar Jaringan/offline (Luring), menggunakan televisi, radio, modul belajar mandiri dan lembar kerja, bahan ajar cetak, alat peraga dan media belajar dari benda di lingkungan sekitar (Kemendikbud 2, 2020). Penelitian yang dilakukan oleh (Yunitasari \& Hanifah, 2020) yang menunjukkan bahwa pembelajaran daring pada masa pandemi COVID-19 sangat berpengaruh terhadap minat belajar siswa, siswa merasa bosan karena tidak bertemu dengan teman dan gurunya secara langsung. Penelitian yang dilakukan oleh (Azizah et al., 2021) yang menunjukan bahwa pembelajaran jarak jauh dapat baik sebelum pandemi dan selama pandemi berpengaruh terhadap minat belajar 
siswa, dan penelitian yang dilakukan oleh (Sobron et al., 2019) menunjukan bahwa daring learning berpengaruh terhadap hasil belajar IPA siswa.

Belajar IPA merupakan sikap kecenderungan mencari tahu seorang siswa dalam melakukan aktivitas mental berpikirnya untuk menemukan pengetahuan baru. Kegiatan belajar IPA seseorang dipengaruhi salah satu faktor internal yaitu minat belajar. Minat belajar dan hasil belajar merupakan dua komponen yang saling berhubungan satu sama lain. Minat belajar merupakan faktor internal seseorang yang muncul sebagai kencenderungan yang tetap untuk memperhatikan dan mengenang kegiatan belajarnya (Raresik et al., 2016). Minat seseorang terhadap belajar mengandung unsur perasaan, kesenangan, kecenderungan hati, dan kesediaan menerima sesuatu dari luar (Achru, 2019). Djamariah mendefinisikan minat belajar sebagai kecenderungan yang menetap untuk memperhatikan dan mengenang beberapa aktivitas belajar secara kosisten dengan rasa senang (Awe \& Benge, 2017).

Pembelajaran dari rumah (BDR) terdapat banyak kendala yang dihadapi siswa maupun guru mata pelajaran yakni pada saat melaksanakan proses belajar terdapat banyak siswa yang kurang konsentrasi dengan mata pelajaran, kesulitan memahami pelajaran, tidak ada yang mendampingi siswa pada saat belajar, siswa tidak bisa bertanya langsung kepada guru berkaitan dengan kesulitan yang didapat pada saat belajar, siswa cepat merasa bosan, tidak memiliki jaringan internet, dan tidak memiliki perangkat digital seperti (handphone, smartphone, laptop, tablet). Berdasarkan masalah yang terjadi selama pandemi serta kajian dari beberapa teori diatas maka tujuan penelitian ini adalah untuk mengetahui minat belajar dan hasi belajar IPA siswa SMPN 1 Nangapanda kelas VII di masa pandemi Covid-19.

\section{METODE PENELITIAN}

Minat dan hasil belajar IPA siswa SMP kelas VIII diperoleh melalui penelitian ex post facto. Subjek penelitian adalah siswa kelas VIII SMP Negeri 1 Nangapanda Kecamatan Nangapanda Kabupaten Ende yang berjumlah 55 orang. Prosedur pengumpulan data dilaksanakan melalui sumber primer dan sekunder. Minat belajar diperoleh dari sumber primer melalui angket yang disebarkan pada siswa-siswi kelas VIII SMP Negeri 1 Nangapanda tahun pelajar 2020/2021. Angket dalam penelitian ini berjumlah 20 pernyataan yang menggunakan 5 alternatif pilihan yaitu sangat baik (5), baik (4), cukup baik (3), kurang baik (2. dan tidak baik (1). Instrument angket memiliki validitas dan reliabilitas melalui professional expert judgment dalam bentuk indeks Gregory (Retnawati, 2016) sebesar 0,8 atau kategori tinggi menurut kategori Wardani dan Slamento (Anggraini Fitrianingtyas \& Radia, 2019).

Minat belajar diperoleh dengan menghitung jumlah skor seluruh butir instrumen, dan rata-rata skor diperoleh dengan rumus:

$$
\hat{X}=\frac{\text { sskor }}{\text { banyaknyabutir }}
$$

Interval rerata skor minat belajar diperoleh dengan menggunakan rentangan persamaan berikut:

$$
\text { Rentang skala }=\frac{\text { Jumlahbutir } x(\text { Skormaksimum-skorminimum })}{\text { Skormaksimum }}
$$

Berdasarkan persamaan ini maka panjang rentang skor untuk 20 butir instrument minat dengan skor maksimum 5 dan skor minimum 1 adalah sebesar 1,8. Rentang jumlah skor dan rerata skor tampak pada Tabel 1 berikut. 
136 Profil Minat dan Hasil Belajar IPA Siswa Melalui Belajar dari Rumah pada Masa Pandemi Covid-19 di Sekolah Menengah Pertama - Andrianus Nggong, Adrianus Nasar, Hamsa Doa

DOI: https://doi.org/10.31004/edukatif.v4i1.1723

Tabel 1. Rentang Jumlah Skor dan Rerata Skor Minat Belajar

\begin{tabular}{lll}
\hline Interval minat belajar & Rerata Skor & Kualifikasi minat belajar \\
\hline $20-35$ & $1 \leq \mathrm{X} \leq 1,8$ & Sangat kurang \\
\hline $36-51$ & $1,8<\mathrm{X} \leq 2,6$ & Kurang Baik \\
\hline $52-67$ & $2,6<\mathrm{X} \leq 3,4$ & Cukup baik \\
\hline $68-83$ & $3,4<\mathrm{X} \leq 4,2$ & Baik \\
\hline $84-100$ & $4,2<\mathrm{X} \leq 5$ & Sangat baik \\
\hline Sumber: (Gulo \& Sulandari, 2016) & &
\end{tabular}

Profil minat dinyatakan dalam persentase dengan rumus:

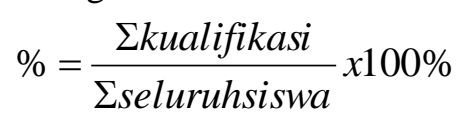

Hasil belajar merupakan hasil yang diperoleh siswa pada aspek pengetahuan yang interval dan kualifikasi ditampilkan dalam Tabel 2 berikut:

Tabel 2. Rentang Interval dan Kualifikasi Hasil Belajar

\begin{tabular}{ll}
\hline Interval Hasil belajar & Kualifikasi hasil belajar \\
\hline$<70$ & Kurang Baik \\
\hline $70-74$ & Cukup baik \\
\hline $75-85$ & Baik \\
\hline $86-100$ & Sangat baik \\
\hline Sumber: (Ginting \& Permana, 2018)
\end{tabular}

\section{HASIL DAN PEMBAHASAN PENELITIAN}

\section{HASIL}

Minat diperoleh dengan menggunakan angket kemudian hasil angket diubah menjadi data dalam bentuk skor. Jumlah skor akan menunjukan profil minat belajar. Data profil minat belajar berdasarkan jumlah skor ditampilkan pada Tabel 4.1 berikut.

Tabel 3. Profil Hasil Minat Belajar

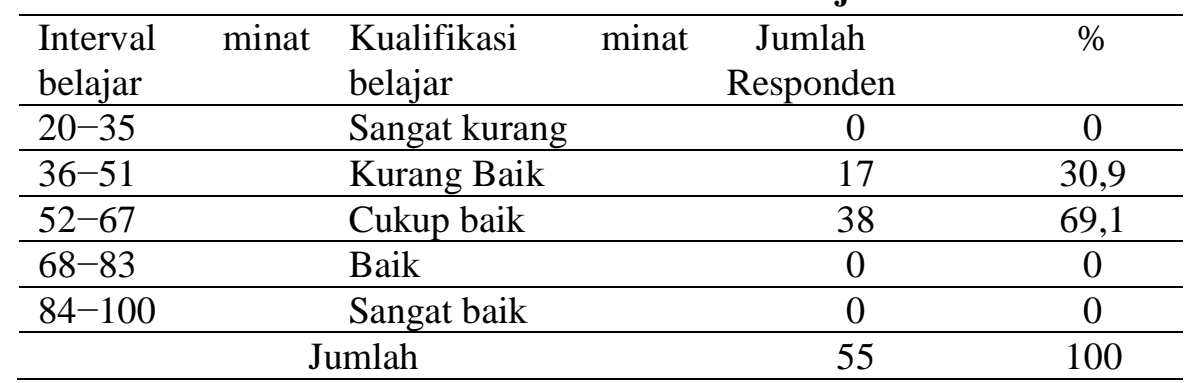

Profil minat belajar ditampilkan dalam bentuk grafik pada Gambar 1 berikut. 
137 Profil Minat dan Hasil Belajar IPA Siswa Melalui Belajar dari Rumah pada Masa Pandemi Covid-19 di Sekolah Menengah Pertama - Andrianus Nggong, Adrianus Nasar, Hamsa Doa

DOI: https://doi.org/10.31004/edukatif.v4i1.1723

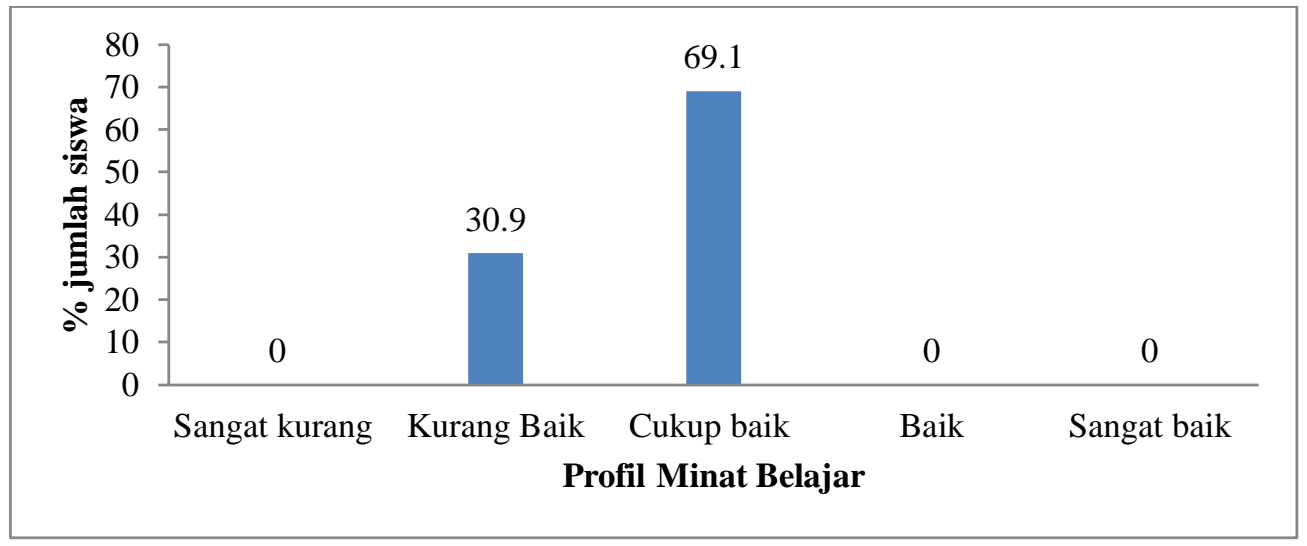

Gambar 1 Grafik Profil Minat Belajar

Berdasarkan tabel dan grafik diatas terdapat 17 siswa dengan kualifikasi minat belajar kurang baik berpersentase 30,9\%. Sedangkan terdapat 38 siswa dengan kualifikasi minat belajar cukup baik berpersentase $69,1 \%$. Profil komponen minat belajar mencakup tampak dalam Tabel 4.2 berikut:

Tabel 4. Profil Komponen Minat Belajar

\begin{tabular}{lllll}
\hline No & Komponen Minat Belajar & $\begin{array}{l}\text { Kode } \\
\text { komponen }\end{array}$ & $\begin{array}{l}\text { Rata-rata } \\
\text { Skor }\end{array}$ & Kualifikasi \\
\hline 1 & $\begin{array}{l}\text { Perasaan senang/termotivasi } \\
\text { dalam kegiatan belajar mengajar. }\end{array}$ & K1 & 3.18 & Cukup baik \\
\hline 2 & Partisipasi dalam pembelajaran & K2 & 3.06 & Cukup baik \\
\hline 3 & $\begin{array}{l}\text { Perhatian/pemahaman dalam } \\
\text { kegiatan belajar mengajar. }\end{array}$ & K3 & 3,28 & Cukup baik \\
\hline
\end{tabular}

Profil Komponen Minat Belajar dapat ditampilkan pada grafik Gambar 2 berikut:

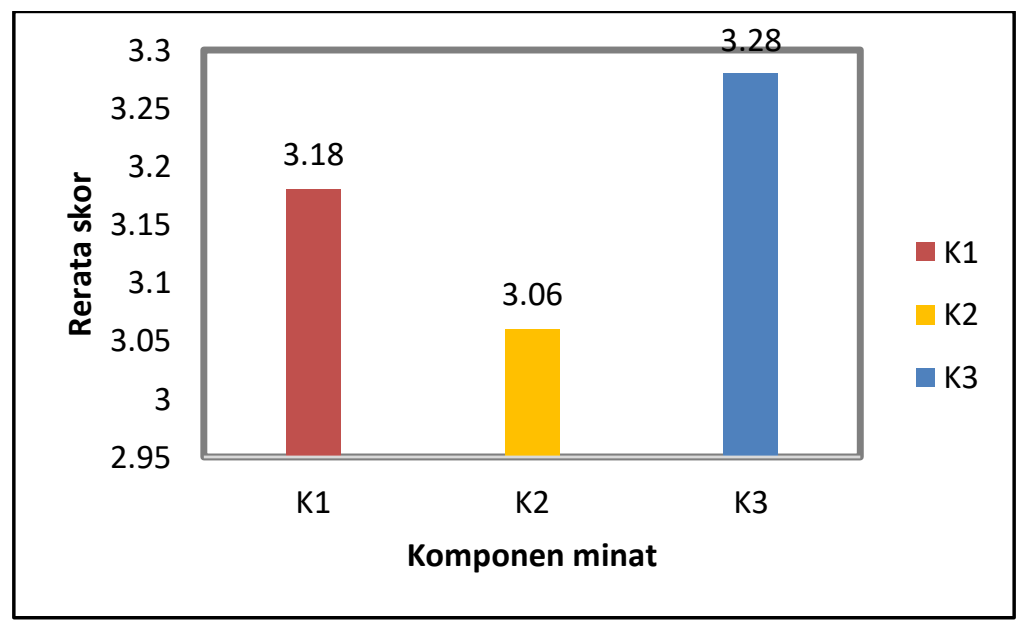

\section{Gambar 2 Grafik Profil Minat Belajar}

Berdasarkan tabel dan grafik di atas dapat disimpulkan bahwa komponen minat belajar berada pada kualifikasi minat belajar cukup baik. 
Data hasil belajar siswa dalam penelitiaan ini diperoleh dengan menggunakan dokumentasi hasil belajar siswa berupa nilai rapor hasil ujian akhir semester genap tahun ajaran 2020/2021. Profil hasil belajar dalam penelitiaan ini adalah siswa SMPN 1 Nangapanda tahun pelajaran 2020/2021 yang berjumlah 55 orang ditampilkan dalam Tabel 5 berikut.

Tabel 5 Profil Hasil Belajar Siswa

\begin{tabular}{cccc}
\hline Interval Hasil Belajar & Kualifikasi Hasil Belajar & Jumlah Responden & $\%$ \\
\hline$<70$ & Kurang Baik & 6 & 10,91 \\
\hline $70-74$ & Cukup baik & 23 & 41,82 \\
\hline $75-85$ & Baik & 26 & 47,27 \\
\hline $86-100$ & Sangat baik & 0 & 0 \\
\hline & Jumlah & 55 & 100 \\
\hline
\end{tabular}

Profil hasil belajar ditampilkan dalam bentuk grafik pada Gambar 3 berikut.

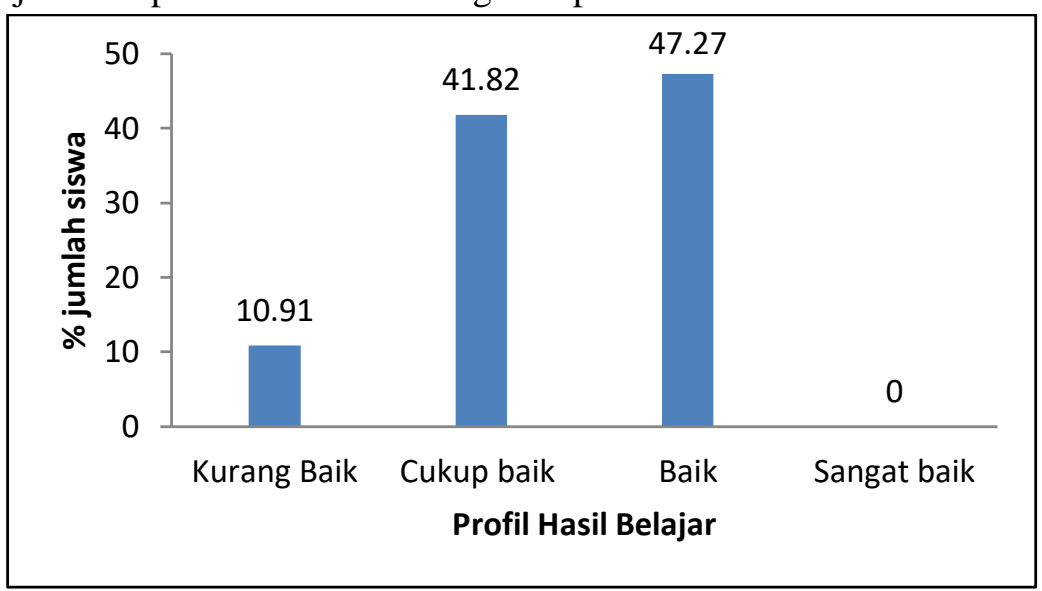

Gambar 3 Grafik Profil Hasil Belajar

Berdasarkan tabel dan grafik di atas siswa berpersentase 10,91\% dengan kualifikasi hasil belajar kurang baik berjumlah 6 siswa. siswa berpersentase 41,82\% dengan kualifikasi hasil belajar cukup baik berjumlah 23 siswa. Sedangkan siswa yang berpersentase $47,27 \%$ dengan kualifikasi baik berjumlah 26 siswa.

\section{PEMBAHASAN}

Pembelajaran IPA di SMPN 1 Nangapenda dilaksanakan melalui belajar dari rumah (BDR) akibat dari munculnya pandemi covid-19. Tujuan BDR ini adalah agar tetap terciptanya proses pembelajaran selama masa pandemi covid-19 dan memastikan pemenuhan hak siswa untuk mendapakan layanan pendidkan selama pandemi covid-19, serta mencegah penyebaran dan penularan pandemi Covid-19 di satuan pendidikan. Pelaksanaan BDR ini untuk mempengaruhi minat dan hasil belajar siswa.

Minat belajar merupakaan kecenderungan siswa dalam melakukan kegiatan belajar yang didorong oleh hasrat untuk mencapai prestasi hasil belajar sebaik mungkin. Minat ini tumbuh karena adanya keinginan untuk mengetahui dan memahami sesuatu mendorong serta mengarahkan minat belajar siswa sehingga lebih sungguh-sungguh dalam belajarnya. Hasil penelitian tentang profil minat dengan komponen perasaan senang/termotivasi dalam kegiatan belajar mengajar, partisipasi dalam pembelajaran, perhatian/pemahaman dalam kegiatan belajar mengajar. 
Belajar siswa melalui belajar dari rumah pada siswa kelas VIII SMPN 1 Nangapanda pada masa pandemi Covid-19 tahun pelajaran 2020/2021 adalah 69,1\% berada pada kualifikasi cukup baik dan 30,1\% berada pada kualifikasi kurang baik. Minat belajar ini dipengaruhi oleh berbagai faktor seperti persaan senang, perhatian dan minat siswa, hal ini sejalan dengan penelitiaan (Dalimunthe et al., 2020). minat belajar siswa pada mata pelajaran IPA di masa Pandemi Covid-19 terbentuk karena siswa menyukai pembelajaranb bdr seperti perasaan senang siswa, perhatian siswa dan semangat.

Hasil belajar dapat diartikan sebagai hasil maksimum yang telah dicapai oleh seseorang siswa setelah mengalami proses belajar mengajar dalam mempelajari materi pelajaran tertentu. Hasil belajar tidak mutlak berupa nilai saja, akan tetapi dapat berupa perubahan, penalaran, kedisiplinan, keterampilan dan lain sebagainya yang menuju pada perubahan positif. Hasil belajar IPA melalui belajar dari rumah pada siswa kelas VIII SMPN 1 Nangapanda pada masa pandemi Covid-19 tahun pelajaran 2020/2021 adalah siswa yang berpersentase 47,27 \% dengan kualifikasi hasil belajar baik, siswa berpersentase 41,82\% dengan kualifikasi hasil belajar cukup baik dan siswa berpersentase 10,91\% dengan kualifikasi hasil belajar kurang baik. Hasil belajar ini dipengaruhi oleh berbagai faktor seperti, sistem pembelajaran, media pembelajaran dan faktor psikis siswa. Hal ini sejalan dengan penelitian yang dilakukan oleh Samari yaitu hasil belajar IPA dalam pembelajaran daring dapat dikatakan masih baik dan masih dapat dilakukan proses pembelajarannya walau dipengaruhi oleh beberapa faktor seperti fasilitas, sarana prasarana dan aktivitas belajar (Samari, 2020).

\section{KESIMPULAN}

Berdasarkan hasil penelitian pembelajaran jarak jauh (BDR) kelas VII SMPN 1 Nangapanda selama masa pandemi Covid 19 terhadap minat belajar yang dinilai berdasarkan komponen minat belajar siswa ratarata semua komponen berkualifikasi cukup baik dan hasil belajar siswa berkualifikasi cukup baik.

\section{UCAPAN TERIMA KASIH}

Terima kasih kepada program studi Pendidikan Fisika FKIP Universitas Flores yang memberi kesempatan kepada kami untuk menyelesaikan penelitian ini.

\section{DAFTAR PUSTAKA}

Achru, A. P. (2019). Pengembangan Minat Belajar Dalam Pembelajaran. Idaarah: Jurnal Manajemen Pendidikan, 3(2), 205. Https://Doi.Org/10.24252/Idaarah.V3i2.10012

Anggraini Fitrianingtyas, \& Radia, E. H. (2019). Peningkatan Hasil Belajar Ipa Melalui Model Discovery Learning Siswa Kelas Iv Sdn Gedanganak 02. 1, 708-720.

Awe, E. Y., \& Benge, K. (2017). Hubungan Antara Minat Dan Motivasi Belajar Dengan Hasil Belajar Ipa Pada Siswa Sd. Journal Of Education Technology, 1(4), 231. Https://Doi.Org/10.23887/Jet.V1i4.12859

Azizah, Rahman, A., \& Ma'as, D. (2021). Pengaruh Pembelajaran Jarak Jauh (Pjj) Luring Terhadap Hasil Belajar Siswa Sd. Jurnal Pendidikan Tambusai, 5(1), 1743-1749.

Dalimunthe, R., Harahap, R., \& Harahap, D. (2020). Analisis Minat Belajar Siswa Sekolah Dasar Terhadap Mata Pelajaran Ipa Pada Masa Pandemi Covid-19. Jurnal Basicedu, 3(2), 524-532.

Ginting, E., \& Permana, Y. (2018). Pedagogi: Penilaian Hasil Belajar (Modul Pengembangan Profesional Berkelanjutan). 1-77.

Godber, K. A., \& Atkins, D. R. (2021). Covid-19 Impacts On Teaching And Learning: A Collaborative Autoethnography By Two Higher Education Lecturers. Frontiers In Education, 6(July), 1-14. 
140 Profil Minat dan Hasil Belajar IPA Siswa Melalui Belajar dari Rumah pada Masa Pandemi Covid-19 di Sekolah Menengah Pertama - Andrianus Nggong, Adrianus Nasar, Hamsa Doa DOI: https://doi.org/10.31004/edukatif.v4i1.1723

Https://Doi.Org/10.3389/Feduc.2021.647524

Gulo, Y. S., \& Sulandari, S. A. (2016). Profil Minat Siswa Sma Kabupaten Nias Barat Terhadap Pelajaran Fisika. Prosiding Pertemuan Ilmiah Xxx Hfi Jateng \& Diy, Hal, 93-95.

Kemendikbud 1. (2020). Surat Edaran Menteri Pendidikan Dan Kebudayaan Nomor 4 Tahun 2020 Tentang Pelaksanaan Kebijakan Pendidikan Dalam Masa Darurat Penyebaran Coronavirus Disease (Covid-19). $1-3$.

Kemendikbud 2. (2020). Surat Edaran Sekretaris Jenderal Kemendikbud Nomor 15 Tahun 2020 Tentang Pedoman Penyelenggaraan Belajar Dari Rumah Dalam Masa Darurat Penyebaran Corona Virus Disease (Covid-19). 35.

Pokhrel, S., \& Chhetri, R. (2021). A Literature Review On Impact Of Covid-19 Pandemic On Teaching And Learning. Higher Education For The Future, 8(1), 133-141. Https://Doi.Org/10.1177/2347631120983481

Raresik, K. A., Dibia, I. K., \& Widiana, I. W. (2016). Analisis Faktor-Faktor Yang Mempengaruhi Hasil Belajar Bahasa Indonesia Pada Siswa Kelas V Sd Gugus Vi. Mimbar Pgsd Undiksha, 4(1), 3.

Retnawati, H. (2016). Analisis Kuantitatif Instrumen Penelitian (Panduan Peneliti, Mahasiswa, Dan Psikometrian.

Samari, S. Y. (2020). Analisis Hasil Belajar Ipa Dalam Pembelajaran Daring Di Sdn Tanjungsari. Jikap Pgsd: Jurnal Ilmiah Ilmu Kependidikan, 4(3), 227. Https://Doi.Org/10.26858/Jkp.V4i3.14753

Siahaan, M. (2020). Dampak Pandemi Covid-19 Terhadap Dunia Pendidikan. Jurnal Kajian Ilmiah, 1(1), 7380. Https://Doi.Org/10.31599/Jki.V1i1.265

Sintema, E. J. (2020). Effect Of Covid-19 On The Performance Of Grade 12 Students: Implications For Stem Education. Eurasia Journal Of Mathematics, Science And Technology Education, 16(7), 1-6. Https://Doi.Org/10.29333/Ejmste/7893

Sobron, A. ., Bayu, Rani, \& Meidawati, S. (2019). Pengaruh Daring Learning Terhadap Hasil Belajar Ipa Siswa Sekolah Dasar Abstrak. Seminar Nasional Sains \& Entrepreneurship, 1(1), 1-5.

Yunitasari, R., \& Hanifah, U. (2020). Pengaruh Pembelajaran Daring Terhadap Minat Belajar Siswa Pada Masa Covid 19. Edukatif: Jurnal Ilmu Pendidikan, 2(3), 232-243. Https://Doi.Org/10.31004/Edukatif.V2i3.142 